\title{
Hinduism and Universality in Religion
}

\author{
Kusumita P. Pedersen
}

\author{
Email: kusumita@igc.org
}

\begin{abstract}
The essay first considers the meaning of the terms "Hindu" and "Hinduism" and whether we can speak of a single "Hinduism." After discussion of critiques of the term "religion" an account of religion as worldview, ethics and practice, following Geertz and Smart, is proposed. Two senses of "universality" as descriptive and prescriptive are explained, with corresponding senses of "pluralism." Illustrative Hindu texts are mentioned along with Brereton's overall characterization of Hinduism. Drawing on Lorenzen, Nicholson and others it is noted that a selfconscious identity of "Hindu dharma" emerged centuries before the colonial period. The essay then turns to Swami Vivekananda's account of universal dimensions of "Hinduism" in the context of religious diversity. He affirms both senses of universality along with an inclusive pluralism rooted in Vedāntic norms and views religion as the universal aspiration for union with one sacred Reality reachable by varied paths and described by different doctrines.
\end{abstract}

\section{Hinduism and Universality in Religion: The Word "Hinduism"}

What is "Hinduism"? As all introductions to Hinduism tell us, the word "Hinduism" is not of Indian origin. Rather it derives from "sindhu," meaning river or stream, and is a geographical term used first by ancient Persians and then by the Greeks and Arabs. "Hindu" referred to the land beyond the river Indus and also to its people - that is, to India and the Indians. The ethnic connotations of the term came to include culture and religion, yet its ambiguity in meaning both territory and tradition persists down to the present. ${ }^{1}$

\footnotetext{
${ }^{1}$ Sharma (2002).
} 


\section{American Journal of Indic Studies Volume 1 Number 1 April 2018}

Over twenty centuries later British missionaries, Orientalists and colonial rulers began to refer to the doctrine or religion of the Indians who were not Muslims or Christians as "Hindooism." The word was in use by the late eighteenth century ${ }^{2}$ and its meaning was forged over the next one hundred years and more. While some have suggested that "Hinduism" is an invention of British colonialism, the building of an understanding of "Hinduism" in the modern period had a foundation in previous history. It also was a joint project of both Europeans and Indian Hindus, as Brian Pennington, David Kopf and others have detailed. ${ }^{3}$ If the Hinduism that we see today differs in myriad ways from that of the past in both its forms and self-interpretation, the same could be said of almost any other religion.

These developments and the mistaken impression that there was not a general term before the eighteenth century for the religion of Indians who were not Muslims, Christians, Jains, Sikhs or Buddhists have led to the claim that there was and is no Hinduism as a single "religion." Hinduism, it has often been said, is a group of traditions which because of their diversity cannot be referred to as one entity having some "essence," or real existence apart from its many variations. But as Will Sweetman has pointed out, "Disassociating oneself from the inevitable process of selection that underlies our use of this or any other general term (for example, by referring to 'what has come to be called Hinduism'), without specifying an alternative basis for selection merely perpetuates a confusion between conceptual and ontological categories in the study of religion."4 In other words, saying that Hinduism is a group of religions does not tell us how any religion is identified as belonging to the group. Confusion persists with the statement by Hindus themselves

\footnotetext{
${ }^{2}$ I wish to express my indebtedness to colleagues who, in answer to my query, discussed these issues on the Religion in South Asia (RISA) listserv of the American Academy of Religion in February 2016.

${ }^{3}$ Pennington (2005); Kopf (1969).

${ }^{4}$ Sweetman (2003): 350.
} 


\section{American Journal of Indic Studies Volume 1 Number 1 April 2018}

that Buddhists, Jains and Sikhs are "Hindus" - meaning followers of a religion of Indian origin an identification that most Buddhists, Jains and Sikhs reject or ignore. ${ }^{5}$

\section{Problems with "Religion"}

In extensive discussion of these questions by scholars, the idea of the unity of "Hinduism" has been problematized as the imposition of a Western concept of "religion" itself. This critique argues that although "religion" is held by some to be a universal human phenomenon, on examination it is found to be a culture-bound category based on characteristics of the Abrahamic religions. These characteristics include the priority of formal belief, a unified coherent doctrine, a single authoritative scripture as the basis of doctrine, a centralized authority regulating doctrine, and faith in a one supreme personal Deity. None of these, some say, are to be found in "Hinduism." Even more problematic, perhaps, than allegedly Western accounts of the category "religion" is the assumption that " $a$ religion" is a discrete, individual entity. This brings us back to the challenge of definition. What constitutes the boundary between one "religion" and another? Who is authorized to decide what kind of difference and what degree of any kind of difference make up a significant distinction? How bright does the line of separation have to be where one "religion" ends and another begins? Besides recognizing the difficulty of "who is authorized" to judge, we should remember that pragmatic definitions that are elastic and have permeable boundaries can be useful as they are often more capable of application than those that seek to be overly sharp.

\footnotetext{
${ }^{5}$ Long (2011): 1.
} 


\section{American Journal of Indic Studies Volume 1 Number 1 April 2018}

\section{Religion as "Worldview"}

Before looking further into a definition or description of Hinduism, let us look at a characterization of "religion" that can work as an account of a universal human phenomenon without importing criteria from Western religions. This is the account advocated by anthropologist Clifford Geertz and historian and philosopher of religion Ninian Smart. ${ }^{6}$ Both have offered characterizations of religion as worldview. The account of religion as a cultural system embracing a worldview, an ethics and a set of practices embodying that worldview does not determine an emphasis on features that are particular to one religion or group of religions to the neglect of others. ${ }^{7}$ No person or culture is without a worldview, or way of looking at the world - as Geertz says, a "picture of the way things in sheer actuality are." ${ }^{\prime 8}$ A worldview may be thick or thin, consistent or inconsistent, worked out with critical reflection or naïve. This is not to say which worldviews are truer than others, but only to affirm that some picture of reality is needed for meaningful human existence.

"Religious" worldviews are distinguished from "secular" ones by their reference to a higher and fuller reality which Rudolf Otto, Mircea Eliade and others have called "the Sacred"9 also an elastic general term pragmatically adopted. We now can appreciate that when Hindus themselves say that "Hinduism is not really a religion, it's a way of life," the idea of "religion" in this statement is indeed influenced by Christian ideas of religion as "belief" which do not fit well with their experience, as Hinduism prioritizes correct practice over doctrine and allows for

\footnotetext{
${ }^{6}$ Geertz (2000 [1995, 1983]); Pedersen (1989).

${ }^{7}$ Worldview, it is very important to emphasize, is not the same thing as doctrine, dogma or formal religious belief. It is not the monopoly of elites or experts such as philosophers, theologians or regulating institutions. It belongs to all of us, because to function cognitively and live a human life, a worldview of some kind along with its values and set of practices is necessary.

${ }^{8}$ Geertz, Op. Cit., 127.

${ }^{9}$ Otto (1958); Eliade (1959).
} 


\section{American Journal of Indic Studies Volume 1 Number 1 April 2018}

pluralism in belief. On the other hand, the more flexible, inclusive and functional account of religion as worldview, values and set of practices, or "a way of life," fits well and is usable.

\section{The Definition of "Hinduism" and Senses of "Universality"}

Historian David Lorenzen says that he prefers to characterize Hinduism the way that Buddhists describe the person: it has no essence, but there is causal continuity over time. Hinduism was not simply invented in the nineteenth century by European colonists, but neither does it have an "absolute historical continuity." 10 Julius Lipner proposes the analogy of a family, a polycentric phenomenon without necessary "core attributes" that define the phenomenon and with flexible decisions on qualifying criteria. ${ }^{11}$ Gavin Flood draws on "prototype theory" in which some features of what is to be defined are "core" and others are nearer the margins. The boundaries may be fuzzy, there may be overlapping areas with a neighboring entity, but there are clearly typical cases of the thing under consideration and we may adopt a pragmatic "definition." ${ }^{12}$ Such strategies are entirely compatible with the idea of religion as worldview, ethics and practice, an idea that does not in any way require an "essence" or "absolute historical continuity."13

What do Hindus themselves say about all of this? First, Hindus are sure that they are not Muslims or Christians; there the boundary line is bright. Some are prepared to allow that Buddhists, Jains and Sikhs are not Hindus, while some others hold that religions of Indian origin are all "Hindu," even if their adherents reject this designation. The definition of Hinduism as

\footnotetext{
${ }^{10}$ Lorenzen (2011): 253.

${ }^{11}$ Lipner (2010): 7.

${ }^{12}$ Flood (1996): 7-8.

${ }^{13}$ It must be pointed out, however, that all of these observations are just as relevant to the Abrahamic religions, which also have continuously changed and where defining an "essence" is equally problematic.
} 


\section{American Journal of Indic Studies Volume 1 Number 1 April 2018}

"Indian-ism" emphasizing notions of "race" or ethnicity is an important element in the ideology

of Hindu nationalism. ${ }^{14}$ Many claim the name Hindu, while others refuse to use it because of its foreign origin, preferring such indigenous names as Sanātana Dharma, "the eternal (or primordial) Dharma." Vasudha Narayanan comments that although this phrase "has gained some currency in recent centuries...that term remains elitist and is applied more to philosophical interpretations of the religion than to colorful local manifestations of the faith." 15 "Dharma" is still, however, probably the most important word in Indian civilization. It derives from the root $d r$, meaning "support" or "hold together" and has many English translations, including duty, obligation, law, virtue, righteousness, right order - and religion. Many Hindus use the long-established phrase "Hindu Dharma." The word "Hinduism" remains common, and is used habitually even by those Western academics who surround it with disclaimers.

So has there been or is there now a single "religion" which can be called "Hinduism,", even though the word itself was not current until the nineteenth century? If so, how shall we describe it? And in what ways can we describe Hinduism as having "universality," with which we are concerned in this reflection? This brings us to one more definition, that of "universality." I will briefly propose two senses of "universality." The first is empirical and descriptive: what is universal is that which found everywhere. For example, music is a human universal because it can be verified from the evidence that there is no human culture without music. The second is philosophical and prescriptive or normative: what is universal is true everywhere in that it is justified and applicable everywhere. For example, those who accept an ethics of the universality of human rights affirm that all human beings possess human rights by virtue of being human (the moral norm of human dignity). We should bear in mind that for both senses of universality, there

\footnotetext{
${ }^{14}$ Nussbaum (2007); Savarkar (2005 [1923]).

15 Narayanan (1996): 14.
} 


\section{American Journal of Indic Studies Volume 1 Number 1 April 2018}

may be an aspect of pluralism, which we may define as a positive accommodation of plurality (or many-ness) and diversity. For the first or descriptive sense, in phenomena that can be empirically observed, variety of form or function may co-exist with basic similarities; for the second or prescriptive sense, different articulations of truth or normativity may be simultaneously valid as they complement each other. In what follows we will be concerned with both senses of "universality," as well as their inclusion of pluralism. ${ }^{16}$

Turning now to the characterization of Hinduism "as such," Joel Brereton, a leading authority on the Veda, Hinduism's root scripture, does not hesitate to make a general statement. He writes,

The Vedic Upanișads play a critical role in the history of Indic religion. ...Historically, their period was one of transition, when the foundations of classical Hindu religion were established and archaic forms of Vedic religion were superseded. Therefore, many basic elements of Hindu religion were first clearly articulated in the Vedic Upanișads. These include the ideas of karma and rebirth; instructions concerning yoga, meditation, and asceticism, the concept of a self beyond the individual self; and the view that there is a single reality hidden by the multiple forms of the world. ${ }^{17}$

He explains ways in which the teachers in the Upanișads offer an "integrating vision" or worldview, the unifying principle of which is called Brahman, literally "that which expands," the term later used for the formless and infinite Absolute Being in distinction from the personal forms of God including Viṣnu, Śiva and the Goddess. The Upaniṣads are very often cosmic in their focus, containing a number of creation narratives explaining how the universe came into being from a single Source. Their best-known teaching is that the âtman, the self or soul, resides not only in all human beings, but also in all that exists, as a "part" or emanation of the ultimate divine Reality or Brahman. The phrase "all beings" occurs frequently. The Upanișads are deeply preoccupied with

\footnotetext{
${ }^{16}$ For a more detailed discussion of possible senses of "universality," see Pedersen (2009).

${ }^{17}$ Brereton (1990): 116.
} 


\section{American Journal of Indic Studies Volume 1 Number 1 April 2018}

the patterns and forces that make the world a coherent, unified reality, and the correspondences between the microcosm of the human person and the macrocosm of the universe, mediated by the symbol system of ritual. ${ }^{18}$

We also find in the Upanișads the first known discussion in India of reincarnation and karma, a view of "afterlife" and destiny applying to all sentient beings, and present not only in Hinduism but in all the religions of Indian origin. The "basic elements" mentioned by Brereton are subsequently found in the Hindu epics, the Mahābhārata and the Rāmāyana and over time elaborated in many religious sub-traditions and philosophical schools. In the Bhagavad Gîta, Hinduism's best-known scripture and part of the Mahābhārata epic, all these teachings are repeated and extended in a theistic mode, as Krishna, an Avatar or "descent" of the Divine, states that "I am the self seated in the hearts of all beings" $(10.20)^{19}$ and identifies his higher nature as the supreme Purușa or Spirit with the origin of all that exists. The principle of pluralism is found in the earliest scripture, the Rig Veda, and travels through later historical developments: "Truth is one, but sages speak of it in different ways" (Rig Veda 1.164.46). ${ }^{20}$ In the Gìta, Krishna says, "Those who come to me, no matter how they do so - I grant them my grace. Arjuna, all men universally follow my path" (4.11), and "I will give unshakable faith to any devotee who wishes to worship god in any form, as long as he worships with fervent faith...He thus obtains his desires from that god, but indeed it is I who granted them" (7.21-22). Krishna also states that all may come to him, whatever their social status or gender, if they approach him with love and devotion. Thus the scope of the root Hindu scriptures is markedly cosmic, clearly affirms pluralism and also has strong socially inclusive dimensions. This is not to say that every Hindu accepts the Bhagavad

\footnotetext{
18 Olivelle (1996).

${ }^{19}$ References to the Bhagavad Gīta are from George Thompson Translation (2008).

${ }^{20}$ Jamison and Brereton (2014) Vol. 1: 359.
} 


\section{American Journal of Indic Studies Volume 1 Number 1 April 2018}

Gìta as authoritative or agrees with these norms, especially their egalitarian implications, since a soteriological inclusivism may go hand in hand with social exclusion in daily life and religious observance. Nevertheless, it can be suggested that there are common themes in Hindu traditions that have very pronounced universalistic aspects in both senses - and with an explicit pluralism.

\section{The Formation of Hindu Identity}

These common and interrelated themes developed through time as self-conscious Hindu identity took shape. Lorenzen has shown that at least from the time of the Maurya Emperor Aśoka (third century BCE) a clear distinction was made between the śramana ("striver") traditions of Jainism and Buddhism, which do not accept the authority of the Veda, and "Brahmanism," which is founded upon it. As Vedic Brahmanism was succeeded by theistic sub-traditions based on the epics and Purānas (religious texts of myth and history) from one sub-tradition to another the gods may be in varying positions, but "are all part of one single pantheon." In the medieval period surveys of philosophical schools distinguish between the non-Vedic and Vedic doctrines, as do devotional texts collecting biographies of saints. In addition, the contrast is later made between Islam and teachings that accept the Veda as authority and point of reference, and "Hindu" is opposed to Muslim. Lorenzen says, "By about 1400, if not before, there is clear evidence of a conscious religious identity among the followers of 'Hindu dharma' (explicitly so-called)." 21 In the seventeenth century the Jesuit missionary Roberto de Nobili also saw Hindus as a group, which he called "the sect of idolaters." 22 In his study of Indian philosophy Unifying Hinduism, Andrew Nicholson states that Indian intellectuals have been engaged in this unifying process "for more

\footnotetext{
${ }^{21}$ Lorenzen, 272.
}

${ }^{22}$ Lorenzen, 263. 


\section{American Journal of Indic Studies Volume 1 Number 1 April 2018}

than seven hundred years." ${ }^{23}$ When in the first half of the nineteenth century the British Sanskritist H.H. Wilson ${ }^{24}$ and other Orientalists referred to Hinduism as having almost infinite diversity, and in this very statement they indicated that there was an overarching collectivity, as an aspect of which this diversity existed. Lorenzen says, "These colonial-period scholars did not, however, thereby invent Hindu religion. Hindu religion had already long since been invented." 25

If Hinduism was not invented in the nineteenth century, the modern period has nonetheless been a time of great change and creativity. British Orientalists, working side by side with native pandits, made use of their training in Latin and Greek classics to learn Sanskrit and retrieve and study the Vedas and Bhagavad Gìta as well as religious texts of the classical period. Though this may not have been their intention, their research helped make available to educated Hindus the primary texts of their tradition and moreover Indians became well aware of the Protestant view of religion as scripture-based. To respond to the challenge of colonial domination and Christian triumphalism which subjected them to vehement criticism of their beliefs and practices, Hindu intellectuals made use of the very historical and text-based method introduced to them by the British. In time, they also made use of British education if they had received it. Drawing on these resources and also indigenous ones, a number of reform movements were founded; more generally there was a ferment of spiritual search and philosophical reflection. A new theological selfdefinition was created. ${ }^{26}$ Its strategies were to return to historical foundations, to separate "the kernel from the husk" and, as often happens in the context of the encounter of diverse cultures and religions, to place stress on universalist ethics and epistemologies (at times based on spiritual

\footnotetext{
${ }^{23}$ Andrew J. Nicholson (2014): 202.

24 As referred to by Lorenzen: 265.

${ }^{25}$ Loenzen: 272.

${ }^{26}$ See Pedersen (1989): 35-46.
} 


\section{American Journal of Indic Studies Volume 1 Number 1 April 2018}

experience and yoga, as we shall see shortly). Some have called this period of creativity "the Hindu renaissance," which was at first centered in Bengal and then spread far beyond that region.

\section{Swami Vivekananda}

The most influential figure in this new theological self-definition in the nineteenth century is Swami Vivekananda. He was born Narendranath Datta in 1862 to an upper-class family in Calcutta, of a cosmopolitan father and a devout Hindu mother. His spiritual search led him first to the Brahmo Samaj, or "Society of God," the earliest and one of the most influential of the Hindu reform movements of modern India. Founded in 1828 by Rammohan Roy, the society prohibited the worship of images, or $p \bar{u} j \bar{a}$, which is central to traditional Hinduism but which Roy viewed as a later accretion and the source of many errors and social ills. He advocated a return to the teachings of the Upanișads, which he translated into Bengali, thus taking the sacred texts out of the hands of Brahmin priests and making them widely available. ${ }^{27}$

At the age of eighteen, with an intense longing for direct knowledge of God, the young Naren came to Sri Ramakrishna, who lived employed as a priest on the grounds of the temple of the Goddess Kali in Dakshineshwar on the outskirts of Calcutta. Ramakrishna is one of the most celebrated mystics in the recorded history of the world's religions. Unlike his famous disciple, he came from a poor village and had little formal schooling. His knowledge came from his immersion in Hindu culture and his realizations in yoga. Ramakrishna had practiced a number of different spiritual disciplines, attaining the goal of God-union in each one. He taught that God both is formless and assumes many forms in order to be known by us - and that the spiritual path of love and devotion, the path of knowledge that discriminates what is real from illusion, and the path of dedicated action or service, are all valid. A single reality may be described in different ways, and

\footnotetext{
${ }^{27}$ See Kopf (1979).
} 


\section{American Journal of Indic Studies Volume 1 Number 1 April 2018}

all religions lead their followers by varied paths to the one goal of God-realization. Naren, later known by his monastic title, Swami Vivekananda, was to become a world-renowned exponent of this teaching of a religious universalism that embraces pluralism. Sri Ramakrishna also instilled in him the teaching of service to all beings as manifestations of God, an ethical universalism in which beneficence applies to all human beings and all life. ${ }^{28}$

In the early days after the Master's passing and becoming a renouncer, Vivekananda had already begun speaking with brother disciples about "the necessity to preach the strength-giving message of the Vedanta philosophy to all, especially to the downtrodden masses." ${ }^{29} \mathrm{He}$ was restless "to do something" yet was unsure what. After a few shorter journeys he began an extended period of wandering, saying, "I shall not return until I gain such realization that my very touch will transform a man." ${ }^{30}$ In Calcutta after his father's death he had endured privation, but now at times was subject to extreme hunger, hardship and danger. He was sometimes refused food and shelter, and was also fed and helped by both the rich and the very poor. He not only suffered himself but also saw the misery of others on a vast scale. The poverty and ignorance of the people of India tortured his heart, and he found its cause to be oppression by the privileged. After three years he ended his journey at the southern tip of India. There he entered into a deep and prolonged pondering in which all that he had experienced was fused into a whole and the vision of what he had to do became clear.

He later wrote from Chicago to a brother monk, "At Cape Cormorin, sitting in Mother Kumari's temple, sitting on a bit of Indian rock, I hit upon a plan: ...Suppose some disinterested Sannyasins [renouncers or monastics], bent on doing good to others, go from village to village,

\footnotetext{
${ }^{28}$ For a detailed account of Sri Ramakrishna and his teachings, see The Gospel of Sri Ramakrishna, translated and with an Introduction by Swami Nikhilananda (1984 [1942]). On the ideal of service, see Beckerlegge, 2006.

${ }^{29}$ Swami Nikhilananda (1964): 76.

${ }^{30}$ Ibid. 85.
} 


\section{American Journal of Indic Studies Volume 1 Number 1 April 2018}

disseminating education and seeking to better the condition of all...we have to give back to the nation its lost individuality and raise the masses..." He adds, "To effect this, the first thing we need is men, and the next is funds." ${ }^{31}$ So it was that he decided to attend the Parliament of Religions soon to take place in America. As he was departing he met two brother monks and said, "I have travelled all over India. But alas, it was agony to me, my brothers, to see with my own eyes the poverty of the masses, and I could not restrain my tears! It is now my firm conviction that to preach religion among them, without first trying to remove their poverty and suffering, is futile. It is for this reason - to find means for the salvation of the poor of India - that I am going to America. "He added, beginning to weep, "My heart has grown much, much larger, and I have learned to feel." He also said, "Such a great power has grown within me that sometimes I feel my whole body will burst." 32

Swami Vivekananda's purpose was to awaken the consciousness of those he would meet in the West through a message that even a child could understand, which would be not merely doctrine but also the teaching of a way of life, though supported with all of the necessary scholarship. He would set forth both the spiritual and philosophical dimensions of this message and also its ethics and consequences for practical life. And he believed, in a spirit of global universalism, that this message would be comprehended by Westerners, as can be seen even in his first speech at the Parliament of Religions in Chicago, given on September 11, 1893. The audience of thousands rose to its feet as he began, "Sisters and Brothers of America." He ended his short address,

The present convention, which is one of the most august assemblies ever held, is in itself a vindication, a declaration to the world, of the wonderful doctrine preached in the Gìta: 'Whosoever comes to me, through whatsoever form, I reach him. All men are struggling through paths which lead to me.' Sectarianism, bigotry,

\footnotetext{
${ }^{31}$ The Complete Works of Swami Vivekananda, $11^{\text {th }}$ ed., Vol. 6, (1978), Letter XLI, 254-55 (hereafter CW).

${ }^{32}$ Nikhilananda, 106, 93.
} 


\section{American Journal of Indic Studies Volume 1 Number 1 April 2018}

and its horrible descendant, fanaticism, have long possessed this beautiful earth. They have filled the earth with violence, drenched it often and often with human blood, destroyed civilization, and sent whole nations to despair. Had it not been for these horrible demons, human society would be far more advanced than it is now. But their time is come; and I fervently hope that the bell that tolled this morning in honor of this convention may be the death-knell of all fanaticism, of all persecutions with the sword or with the pen, and of all uncharitable feelings between persons wending their way to the same goal. ${ }^{33}$

He became famous overnight and until his death in 1902 at the age of thirty-nine, he lectured, wrote, and founded the Vedanta Society in the West while building up the Ramakrishna Mission in India. We will now look further into his view of universality and how it is related to Hinduism.

\section{Swami Vivekananda's Ideal of a Universal Religion}

In his lectures on "The Way to the Realisation of a Universal Religion" and "The Ideal of

a Universal Religion," 34 Swami Vivekananda states that the religions of humanity arise from a single aspiration, which can be found in all times and all cultures, in other words, an aspiration which is universal in the descriptive sense: it can be observed everywhere. He says:

No search has been dearer to the human heart than that which brings us light from God. No study has taken so much human energy, whether in times past or present, as the study of the soul, of God, and of human destiny... Thus it has been throughout the ages in all countries. Man has wanted to look beyond, has wanted to expand himself; and all that we call progress, evolution, has always been measured by that one search, the search for human destiny, the search for God.

Even though religions all come from this single source of human aspiration and "Nothing has made more for peace and love than religion, [at the same time] nothing has engendered more

\footnotetext{
${ }^{33} \mathrm{CW}$, Vol. 1, 3-4.

${ }^{34} \mathrm{CW}$, Vol. 2, 359-396. The following account, including all quotations, is drawn from these two lectures.
} 


\section{American Journal of Indic Studies Volume 1 Number 1 April 2018}

hatred than religion." Still, some religious adherents persist in the view that all "sects" or religious groups should be allowed to live, and even hope for a time when all religious communities will live together in harmony. Vivekananda says that "had it been the will of an all-wise and allmerciful creator that one of these religions should alone exist and the rest die, it would have become fact long, long ago. If it were a fact that only one of these religions was true and all the rest were false, by this time it would have covered the whole world. But this is not so." Instead, "sects" constantly multiply with contending interpretations even of a single scripture. And indeed, he says, "So long as mankind thinks, there will be sects. Variation is the sign of life," and when there is no diversity, religion will be dead. "Unity in variety is the plan of the universe."

Such being the case, how are we to judge between the apparent challenges to universality of the different "truth-claims" of these many religions? "How can all this variety be true?" Swami Vivekananda asks. "How can contradictory opinions be true at the same time?" Commenting that "I took up this question when quite a boy, and have been studying it all my life," he offers his conclusion: “...they are not contradictory, they are supplementary. Each religion, as it were, takes up one part of the great, universal truth, and spends its whole force in embodying and typifying that part of the great truth. It is therefore addition, not exclusion....ideals must be added to ideals. And that is how humanity marches on." Nonetheless in the vast global aggregation of countless different apprehensions of truth, there is still an underlying oneness, because the Source of all being and of humanity's aspiration is One. The many teachings "all point to the same thing." The variety of emphasis and expression results from varied perspectives, looking at reality from different directions. "Yet we all belong to the same great, universal truth," Vivekananda declares. The utterance of the Rig Veda, "Truth is one, but sages speak of it in different ways" is for 


\section{American Journal of Indic Studies Volume 1 Number 1 April 2018}

Vivekananda a foundational statement of universality of truth embracing pluralism, ${ }^{35}$ as is the verse from the Bhagavad Gìta mentioned above, quoted in his inaugural speech at the World Parliament of Religions, in which he also speaks of "persons wending their way to the same goal." Each religion, Vivekananda says, has "a particular excellence, something which is its soul." And in spite of all their errors, the accumulation of dogmas and rituals, and conflicts between religions, "the heart of every one of them is sound - it is a throbbing, beating, living heart." This heart and the central idea held up by a religion constitute what Vivekananda calls its "mission" in the world. A significant aspect of Vivekananda's universalism is that he is convinced that we are able to discern, based on values we all share, what is excellent and beneficial in each religion, distinguishing it from what is non-essential or even harmful. The scope of this essay does not permit further treatment of ethics, except to say that common moral rules found in most traditions are present in Hinduism. Vivekananda does not state (as some have incorrectly said) that "all religions are the same;" on the contrary, he states that they are different, as they provide complementary manifestations of a single truth. And this one truth is not the "least common denominator" of the religions, but the great totality holding within itself the boundless, variegated richness of all religions. It is also a transcendent reality surpassing even this visible totality, while the religions themselves continue to grow into new forms. Jeffery Long points out that this view of religious diversity is neither relativism nor absolutism, but is a third way or middle path. Its acceptance not only can enrich each religion through learning from others, but also "has definite implications for human conduct" as we try to progress beyond conflict towards interfaith harmony. ${ }^{36}$ Francis X. Clooney comments that Vivekananda "taught an inclusive universalism that

\footnotetext{
${ }^{35}$ See, for example, "Vedic Religious Ideals," CW Vol. 1, 348 and 349; he repeats the verse three times as he stresses its central importance.

${ }^{36}$ Long (2013): 6.
} 


\section{American Journal of Indic Studies Volume 1 Number 1 April 2018}

explained how religions might thrive in their particularity, while yet pointing beyond themselves to a more universal truth that only mature religious persons - proponents of Vedanta, for instance - could adequately recognize. Honor is given to individuals who cultivate higher consciousness and see the deeper and higher meaning implicit in all traditions." 37

Because variation is a law of life and will always manifest itself, the universal aspect of religion is not to be found in any of the three main external aspects of religion - philosophy, mythology and ritual — and will not emerge there in the future any more than it occurs there today. The universal religion, Vivekananda says, will not be one single philosophy, myth or ritual that is adopted by all. "Where, then, is there any universality in religion? How is it possible, then, to have a universal form of religion? I am convinced that that form of religion already exists. Let us see what it is." Vivekananda at this point turns away from concern with the phenomena of doctrine, myth and ritual and refers again to the aspiration for God that all people share. This empirical observation is joined with a constructive philosophy of being; he takes as the frame of his ideal of a universal religion the ontological affirmation that God is one and all existence, which comes forth from God, is one. Humanity is one and it is God within each of us - our soul or true self that aspires to unite consciously with our divine Source. All of humanity's religious forms are "consciously or unconsciously struggling upward toward God," because "each one of us is trying to arrive at the realization of God."

Vivekananda's universalism is rooted in the Vedānta philosophy of the Upanișads, the Bhagavad Gìta and the classical philosophical traditions of Hinduism. It also reflects the teaching of his spiritual Master Sri Ramakrishna that diverse spiritual paths all lead to the one goal of conscious union with God. Vivekananda, himself a yogi and a mystic, affirms that "The end of all

\footnotetext{
${ }^{37}$ Clooney (2010): 81.
} 


\section{American Journal of Indic Studies Volume 1 Number 1 April 2018}

religions is the realizing of God in the soul. That is the one universal religion. If there is one universal truth in all religions, I place it here, in realizing God." At the same time, this goal of God-realization is multi-faceted and can be achieved in different ways. He affirms not that religions "are the same" but that along with their distinctive excellences or missions, they do share what is of highest value. In his account overall, this normative theological statement about what must be universally of value goes hand in hand with his evidence-based descriptive statement that aspiration for God or the search for truth can be found among people everywhere.

Vivekananda believes that the universal human aspiration to become one with God or the ultimate Reality can be mapped onto an integrated structure of diverse spiritual methods or practices. While known in India as Yoga, Vivekananda would say that these spiritual methods exist in many traditions worldwide. Vivekananda is well known for his exposition of the four Yogas as the paths of knowledge, love, work as service, and meditation. Since human beings vary in their dispositions a single way is not suitable for all; there must be a variety of approaches. Vivekananda compares the myriad approaches to the radii of a circle converging on the center, which is God or Truth. The "excellence" of each religion is in the way it develops a particular aspect of this whole range of possibilities - spiritually, ethically and culturally.

In summarizing Vivekananda's constructive philosophy, or theology, of universality, he affirms both its descriptive and prescriptive senses and incorporates pluralism into both. He states that the experience of longing for the Divine is found everywhere, and also believes that moral values are consistent across cultures. This can be demonstrated, he would say, from the evidence. From the standpoint of normative theological ethics, he powerfully affirms that all human beings, without regard to ethnicity, race, or gender are equal in dignity because God dwells in all - indeed all living beings are worthy of love and service for the same reason. Epistemologically, his 


\section{American Journal of Indic Studies Volume 1 Number 1 April 2018}

universalism is a pluralism that holds that experiences and expressions of truth are conditioned by different but valid perspectives from each of which the one ultimate Reality can be approached and seen. While belief in karma and reincarnation might not be universal in the descriptive sense of "found everywhere," one who does believe in it as Vivekananda does will assert that it applies to all beings without exception. Finally, Vivekananda holds that the goal of religious life, enlightenment or realization, is in principle accessible to every person, again regardless of nationality or gender, provided that the methods of spiritual discipline or Yoga are employed. India may historically have had an exceptional development of such spiritual practices, he might say, but they are found elsewhere as well - and in any case we now live in a time when they will no longer be restricted to any special group of people but are open to all. His ideal of a universal religion is a philosophy or worldview, an ethics and a system of practices which is inclusive, valid and applicable globally.

Swami Vivekananda says, "An ideal presents itself to my mind. It may be only a dream. I do not know if it will ever be realized in this world, but sometimes it is better to dream a dream than to die on hard facts. Great truths, even in a dream, are good - better than bad facts. So let us dream a dream." He declares, "I accept all religions that were in the past and worship with them all; I worship God with every one of them, in whatever form they worship him...[and] I shall keep my heart open for all the religions that may come in the future. Is God's book finished? Or is revelation still going on?...The Bible, the Vedas, the Koran, and all other sacred books are but so many pages, and an infinite number of pages remain yet to be unfolded. I shall leave my heart open for all of them. We stand at the present, but open ourselves to the infinite future." 


\section{American Journal of Indic Studies Volume 1 Number 1 April 2018}

\section{References}

Beckerlegge, Gwilym. 2006 Swami Vivekananda's Legacy of Service: A Study of the Ramakrishna Math and Mission. New Delhi: Oxford University Press.

Brereton, Joel. 1990. "The Upanișads," in Approaches to the Asian Classics. Ed. Wm. Theodore de Bary and Irene Bloom. New York: Columbia University Press. Pp. 115-135.

Eliade, Mircea. 1959. The Sacred and the Profane. New York: Harcourt Brace Javonovich.

Flood, Gavin. 1996. An Introduction to Hinduism. Cambridge, UK: Cambridge University Press.

Geertz, Clifford. 1973. The Interpretation of Cultures. New York: Basic Books.

Clooney, Francis X., S.J. 2010. Comparative Theology: Deep Learning across Religious Borders. Malden, MA: Wiley-Blackwell.

The Gospel of Sri Ramakrishna. 1984 [1942]. Translated with Introduction by Swami Nikhilananda. New York: Ramakrishna-Vivekananda Center.

Jamison, Stephanie W. and Joel P. Brereton. Tr. 2014. The Rigveda: The Earliest Religious Poetry of India. New York: Oxford University Press.

Kopf, David. British Orientalism and the Bengal Renaissance: The Dynamics of Indian Modernization: 1771-1835. 1969. Berkeley and Los Angeles: University of California Press

1979. The Brahmo Samaj and the Shaping of the Modern Indian Mind. Princeton: Princeton University Press.

Lipner, Julius. 2010. Hindus: Their Religious Beliefs and Practices, $2^{\text {nd }}$ edition. New York: Routledge.

Long, Jeffery D. 2011. Historical Dictionary of Hinduism, New Edition. Plymouth, UK: The Scarecrow Press.

. 2013. "Swami Vivekānanda and Religious Pluralism." Paper delivered at the International Congress of Vedānta.

Lorenzen, David N. 2011, "Hindu Sects and Hindu Religion: Precolonial and Colonial Cocnepts" in Cynthia Talbot, ed., Knowing India: Colonial and Modern Constructions of the Past. New Delhi: Yoda Press. Pp. 251-278.

Narayanan, Vasudha. 1996. "The Hindu Tradition," Chapter One in Willard G. Oxtoby, ed., World Religions: Eastern Traditions, $2^{\text {nd }}$. ed. New York: Oxford University Press. Pp. 12-125.

Nicholson, Andrew J. 2014. Unifying Hinduism: Philosophy and Identity in Indian Intellectual History. New York: Columbia University Press.

Nussbaum, Martha C. 2007.The Clash Within: Democracy, Religious Violence and India's Future. Cambridge, MA: Belknap Press of Harvard University Press.

Nikhilananda, Swami. 1964. Vivekananda: A Biography. Calcutta: Advaita Ashrama.

Olivelle, Patrick. 1996. Upanișads. New York: Oxford University Press.

Otto, Rudolf. 1958. The Idea of the Holy. tr. John Harvey. New York: Oxford University Press.

Pedersen, Kusumita P. 1989. "The Hindu Renaissance in Bengal," World Faiths Insight, New Series 21: 35-46.

2009. "Universality of Moral Norms: A Human Rights Perspective," in Arvind Sharma, ed., The World's Religions after September 11, Westport, CT: Praeger Publishers. Pp. 6977.

Pennington, Brian K. 2005. Was Hinduism Invented? Britons, Indians and the Colonial Construction of Religion. Oxford: Oxford University Press.

Savarkar, V. D. 2005 [1923]. Hindutva. New Delhi: Hindi Sahitya Sadan. 


\section{American Journal of Indic Studies Volume 1 Number 1 April 2018}

Sharma, Arvind. 2002. “On Hindu, Hindustān, Hinduism and Hindutva.” Numen, Vol. 49, No. 1: 1-36.

Smart, Ninian. 1989. The World's Religions. Englewood Cliffs, New Jersey: Prentice Hall. . 2000 [1995, 1983]. Worldviews: Crosscultural Explorations of Human Beliefs, 3rd ed. Upper Saddle River, New Jersey: Prentice Hall.

Sweetman, Will. 2003. "'Hinduism' and the History of 'Religion': Protestant Presuppositions in the Critique of the Concept of Hinduism." Method and Theory in the Study of Religion, Vol. 15, No. 4: 329-353.

Vivekananda, Swami. 1978. Collected Works, Eleventh edition. Calcutta: Advaita Ashama. 